\title{
The Impact of COVID-19 Through the Lens of Islamic Law: An Indonesian Case
}

\author{
Mohammad Syahrul RA \\ Universitas Muhammadiyah Malang, Indonesia \\ ramdhanialmubarok3@gmail.com \\ Yusuf Hamdika \\ Universitas Muhammadiyah Malang, Indonesia \\ dhikayusuf2000@gmail.com \\ Sholahuddin Al-Fatih \\ Universitas Muhammadiyah Malang, Indonesia \\ sholahuddin.alfath@gmail.com
}

\begin{abstract}
Coronavirus Disease 2019 (COVID-19), a virus found in China, has spread worldwide as it has become pandemic. As a result, significant and detrimental impacts are undeniable to global citizens, including those in Indonesia. With the government's suggestions like introducing physical distancing and largescale social restriction, they slow down economic growth. Also, they impact religious practices, particularly those performed by Muslims in Indonesia. This paper will discuss the impact of the COVID19 pandemic through the lens of Islamic law. There are two main issues to analyze. First, what is the impact of COVID-19 on community activities in the view of Islamic law? Second, what is the impact of COVID-19 on religious communities in carrying out worship? This paper finds that the COVID-19 pandemic has adversely impacted religious worship activities in public places by considering this virus's rapid transmission. It is followed by the closure of worship places to encourage citizens to practice their religious activities at home. Thus, the whole community was urged, and some were prohibited following the mapping zone experienced by each region. Given Islamic law is believed and trusted by Muslims, in the end, the government has issued a new normal policy by opening places of worship with health protocols.
\end{abstract}

KEYWORDS: COVID-19, Islamic Law, Religious Practices, Indonesian Muslims.

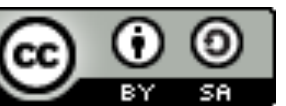

Copyright $\odot 2020$ by Author(s)

This work is licensed under a Creative Commons Attribution-ShareAlike 4.0 International License. All writings published in this journal are personal views of the authors and do not represent the views of this journal and the author's affiliated institutions.

\section{HOW TO CITE:}

RA, Mohammad Syahrul, Yusuf Hamdika \& Sholahuddin Al-Fatih. "The Impact of COVID-19 Through the Lens of Islamic Law: An Indonesian Case" (2020) 7:3 Lentera Hukum 267-278.

Submitted: July 29, 2020 Revised: October 10, 2020 Accepted: November 01, 2020 


\section{INTRODUCTION}

Coronavirus Disease 2019 (COVID-19) has been estimated to spread rapidly since the end of 2019, with Wuhan City, China, indicated as the virus origin. As a result, the Chinese government immediately isolated Wuhan City. The World Health Organization (WHO) has taken considerable measures to address this situation and officially announced that COVID-19 is a new infectious virus. It is claimed that COVID19 is the collection of viruses that can infect the respiratory system and cause death, as it was previously identified as a cause of flu in the 1960s. ${ }^{1}$ It generates a new disease caused by an acute respiratory syndrome commonly known as SARS-CoV-2. ${ }^{2}$ As mentioned by the WHO, COVID-19 causes the common cold to more severe diseases. The virus is commonly transmitted from animals to humans, then transmitted between humans. Common symptoms of COVID-19 include fever, coughing, shortness of breath, and possible muscular pain, sputum production, diarrhea, sore throat, loss of odor, and abdominal pain. ${ }^{3}$ This virus currently remains in the vaccine's absence to prevent spread to the new potential carriers as an infectious disease. Then, the WHO encouraged states to declare a public health emergency in response to this virus pandemic. ${ }^{4}$

In response to this pandemic, each country took immediate measures in combating the fast-spreading virus worldwide. In general, the measure considered the importance of lockdown. However, it should apply the partial lockdown to some extent, which indicated the importance of physical distancing. For instance, the measures are postponing mass travel, restricting mass activities and crowds, closing schools, and limiting working hours for offices or factories. Insofar, Indonesia is among the countries to applying physical distancing. This physical distancing follows the WHO suggestion. This international health agency suggests keeping a minimum distance of one meter from people to prevent the rapid transmission of COVID-19 carrier. This suggestion considered that no one could identify COVID-19. ${ }^{5}$ This measure is applied to prevent COVID-19 transmission. The health protocol is highly recommended, such as washing hands, wearing masks, and avoiding contact with objects that mediate disease's spread by washing between the fingers and washing with running water. It also applies to the congregation's prayer in the mosque with a separate shaf (distance) caused by COVID-19. In this context, COVID-19 can be seen from some aspects, mainly the government's measure against COVID-19 through the

1 Eko Misbahuddin Hasibuan \& Muhammad Yusram, Hukum Salat Berjemaah di Masjid dengan Saf Terpisah Karena Wabah COVID-19, (2020) 1:2 Jurnal Bidang Hukum Islam, at 106-124.

2 Chih Cheng Lai et al., Severe Acute Respiratory Syndrome Coronavirus 2 (SARS-CoV-2) and Coronavirus Disease-2019 (COVID-19): The Epidemic and The Challenges, (2020) 55:3 International Journal Antimicrob Agents 105924.

3 Adèle de Masson et al., "Chilblains is a Common Cutaneous Finding During the COVID-19 Pandemic: A Retrospective Nationwide Study from France" (2020) 83:2 J Am Acad Dermatol, at 667-670.

4 Susilo, Coronavirus Disease 2019: Tinjauan Literatur Terkini, (2020) 7:1 Jurnal Penyakit Dalam Indonesia, at 167.

5 Mukran H Usman, COVID-19 dalam Perjalanan Akhir Zaman: Sebab, Dampak dan Anjuran Syariat dalam Menghadapinya, (2020) 1:2 Jurnal Bidang Hukum Islam, at 137-155. 
lens of the Islamic law that imposes the use of masks for congregational prayers. In Islamic teaching, the concept of tafakkur in Al-Qu'ran deals with COVID-19. It has several options: isolating the area as an appropriate action, be patient, kind, and thoughtful, with prayers that resign the problems to Allah. From social psychology, it deals with citizens' behavior to COVID-19 and that in maintaining mental welfare. ${ }^{6}$

In reality, the violation of health protocols is inevitable, which ignores the government's call in preventing COVID-19. The psychology concept of so-called cognitive bias causes this disobedience. The inevitable panic in major Muslim countries, one of which is in Saudi Arabia, results in the closure of the Grand Mosque for umrah. This country also closes all academic activities in schools and universities, following the measure to shorten Friday sermons and prayers. ${ }^{7}$

The European Council for Fatwa and Research (ECFR), ${ }^{8}$ a Dublin-based private foundation composed of Islamic clerics and scholars presided over by Yusuf AlQardhawi, responds to congregational prayers through social distancing, stating prayers in mosques are temporarily stopped and carried out in their respective homes. The congregational prayers are the sunnah mu'akadah, and it is better to prioritize the obligation to maintain safety and health. Because prayers like what is prescribed by tight shaf will cause a person exposed to this virus because they remain mixed when entering and leaving, prostrate in the same place and when opening the door. ${ }^{9}$ The mosque should be an example of disciplinary enforcement of laws and regulations. This also influences the human soul's protection with caution. Muslims have been encouraged to follow the Shari'a when an epidemic strikes a country: a) avoiding visiting a country affected by the disaster; b) closing the container where the water is; c) praying and pray a lot; and 4) living in the city of Medina or staying at home. There was controversy because of the postponed Umrah and Friday prayers and other Muslim worship's restriction. These limitations imposed by the government to restrict the crowds that may encourage significant virus infection. ${ }^{10}$ The disaster that befell all Muslims in the world happened in the case of COVID-19. For most Muslims, the COVID-19 outbreak is controversial because such a disease disaster was like a plague that attacked them in the past.

COVID-19 outbreaks have occurred with almost the same conditions. To overcome the outbreaks, it is necessary to apply quarantine or isolation to sufferers. Quarantine methods have been applied since the time of the Prophet Muhammad to

6 Dana Riksa Buana, Analisis Perilaku Masyarakat Indonesia dalam Menghadapi Pandemi Virus Corona (COVID19) dan Kiat Menjaga Kesejahteraan Jiwa, (2020) 7:3 Jurnal Sosial dan Budaya Syar-I at 221.

7 Deni Miharja Dadang Darmawan, Roro Sri Rejeki Waluyojati \& Erni Isnaeniah, Sikap Keberagamaan Masyarakat Muslim Menghadapi COVID-19, (2020) 4:2 Jurnal Studi Agama-Agama dan Lintas Budaya, at 1-10.

8 ECFR, "The European Council for Fatwa and Research: Renewed Leadership, Renewed Hopes" (2018).

9 Hasbiyallah et al., Fikih Corona (Studi Pandangan Ulama Indonesia terhadap Ibadah dalam Kondisi Darurat COVID-19), (2020) l:2 Jurnal Fikih Islam, at 1-8.

10 Eman Supriatna, Wabah Corona Virus Disease (COVID-19) dalam Pandangan Islam, (2020) 7:6 Jurnal Sosial Budaya Syar-I FSH UIN Syarif Hidayatullah Jkt, at 555-564. 
prevent the spread of infectious diseases to other regions. Isolating individuals away from the population to avoid transmission of this disease is highly recommended. During isolation, there are health workers or medical personnel who will provide treatment to those who suffer. Officers are also provided exceptional security for health security officers who do not come infected or infected." By considering those as mentioned earlier, it is essential to discuss economic, cultural, and regulatory aspects regarding COVID-19. Several issues discussed in this paper deal with COVID-19 and its impact on community activities. Is it possible to limit community activities into policies supplemented by the community, seeing how many people lack economic and religious people who will carry out worship? One of them is for Muslims who will perform the Eid Adha prayer after the Eid Fitri prayer. Even there is still a government measure to regulate the community. Even the community becomes confused over the many policies that the government exposes.

Previous studies confirmed how to Islam threat to fight against COVID-19 and other potential viruses from the literature review. ${ }^{12}$ Another paper written by Eman Supriatna found that the COVID-19 pandemic is a test from Allah to humankind. Humans can remember Allah over everything about life. ${ }^{13}$ This paper then looks from an Islamic perspective regarding Muslims' pattern of worship during the COVID-19 pandemic. The first part introduces the general background and several problems dealing with Islam and COVID-19. The second part will discuss the impact of COVID19 on Islamic law.

\section{METHODS}

This paper uses a doctrinal approach by interpreting and analyzing legal theories relevant to juridical basis consisting of the principles, conceptions, doctrines, and norms. This approach utilizes library resources as the secondary data obtained from books, journal articles, and relevant documents related to the current COVID-19 issues. The content analysis technique aims to find out the conclusions by revealing the manifested authors' analysis..

\section{THE IMPACT OF COVID-19 ON MUSLIMS FROM ISLAMIC LAW}

Islamic law is based on Al-Qur'an and Hadith. As it is commonly known, Al-Qur'an and Hadith are using the Arabic language. In the Arabic language, the term of waba' or wba, is mainly used for an epidemic. ${ }^{14}$ That term has a different meaning from what is defined by the WHO. While pandemic is a global case, and epidemics or waba' is a local case.

1 Kustana et al., Analisis Kritis Pola Keberagamaan Dalam Perubahan Sosial Ditengah Wabah COVID-19, (2020) 1:No. 2 J Anal, at 1-7.

12 Islam dan COVID-19, by Nur Afifah (Ponorogo, 2020).

13 Eman Supriatna, supra note 10.

14 Zohaib Ahmad \& Arzoo Ahad, COVID-19: A Study of Islamic and Scientific Perspectives, (2020) Theology and Science, at 1-10. 
From Al-Qur'an and Hadith, we understand histories, such as the history of disaster management or pandemic. Disaster management in Islam can at least be explored from stories written in the Al-Qur'an and Hadith. ${ }^{15}$

First, the flood disaster during the Prophet Noah's time lasted for 40 days and 40 nights and killed all living things except those on board the ship of Noah (QS. AshSyu'ara verse: 117-119 \& Q.S. Hud [11]: 25-26). Second, the catastrophic rain of stones at the time of Prophet Luth as in the city of Sodom (now known as the border of Israel Jordan) (QS. Hud [11: 82). Third, the famine lasts for seven consecutive years, narrated in Surah Yūsuf verses 47-49. Fourth, health disasters in the form of outbreaks of infectious diseases (Tha'un) occurred in the land of Shams in the years 638-639 AD (17$18 \mathrm{H}) .{ }^{16}$ Moreover, Hadith literature also mentioned more than fifty traditions that inform about Black Death. ${ }^{17}$ Black Death is a plague that affects humans and animals at an equal rate. ${ }^{18}$ Bintu Syaifah AL-Azizah analyzes 25 Hadith that mentioned several cases in history: three Hadith about the pandemic, 14 Hadith about epidemics, three Hadith about quarantine, and five Hadith about prayer by Prophet to avoid pandemic and outbreak. ${ }^{19}$ Bintu found two pandemic and epidemic in Muhammad's time: First, the Medina Flu pandemic at the beginning of Muhammad did hijrah or migration to Medina. Second, Shirawayh epidemic in Mada'in (Ctesiphon, Iraq) in 629 A.D. ${ }^{20}$

Of the seven disasters or pandemics in Islam above, only Tha'un disasters were relevant to COVID-19. Both have a common issue, and it is a health disaster. As narrated by Bukhari and Muslim, Muhammad said, "If you hear the plague raging in a country, then do not enter it; and if you are in that area, do not go out to run from it." ${ }^{21}$ Aisha, Muhammad's wife, said: "I asked the Messenger of Allah about the plague, he told me that it was punishment sent by Allah on whom he wished, and Allah made it a source of mercy for the believers, for if one in the time of an epidemic plague stays in his place patiently hoping for Allah's Reward and believing that nothing will befall him except what Allah has written for him, he will get the reward of a martyr."22 This Hadith indicates the emergence of an epidemic. ${ }^{23}$ This Hadith becomes relevant to the mitigation of COVID-19, such as lockdowns, self-quarantine, self-isolation, staying at home, and maintaining distance. ${ }^{24}$ That mitigation is also relevant to the impact of

15 Suyadi, Zalik Nuryana \& Niki Alma Febriana Fauzi, The Fiqh of Disaster: The Mitigation of COVID19 in The Perspective of Islamic Education-neuroscience, (2020) 51 International Journal of Disaster Risk Reduction.

16 Ibid.

17 Suzanne Austin Alchon, A Pest in The Land: New World Epidemics in a Global Perspective (Mexico City: University of New Mexico, 2003).

18 Ahmad \& Ahad, supra note 15.

19 Bintu Syaifa Al Azizah, Al-Wabâ wa al-Hijr as-Shihhi fî Dho'i al-Sunnah al-Nabawiyyah al-Syarîfah UIN Syarif Hidayatullah Jakarta, 2020) [unpublished].

20 Ibid.

21 Suyadi, Nuryana \& Fauzi, supra note 16.

22 Muhammad ibn Ismail Bukhari, Sahih al-Bukhari (Beirut: Dar Ibn Katsir, 202AD).

23 Ahmad \& Ahad, supra note 15.

24 Suyadi, Nuryana \& Fauzi, supra note 16. 
COVID-19 as at the time of the COVID-19 pandemic. Most community activities are postponed and canceled.

COVID-19 becomes a severe issue because its impact can leverage people's lives. ${ }^{25}$ Scholars consider obtaining the alternative amidst the search for a drug to cope with COVID-19. To be sure, domestic authorities also take considerable measures in a way to handle this virus as it profoundly affects social, political, and economic issues. It includes education and religious affairs, as analyzed in this paper, taking into account Islamic law. It deals with the extent, the adverse impact of COVID-19 on Muslims' religious practices.

Islamic law is a set of obedience sourced and is a part of Islamic teaching. Unlike other laws, Islamic law does not only the results of human thought are influenced by their culture. However, God's basis is set through His revelation and explained by the Prophet through his sunnah. ${ }^{26}$ Thus, Islamic law does not only theological but also anthropological. Theological aspects are reflected from fundamental norms, whereas anthropological aspects manifest in instrumental or the kaifiyah. ${ }^{27}$ All human beings have different characteristics that assert in Indonesia has been diverse and has vast religions' adherents. It becomes a difference that gives rise to a belief that needs to be carried out in a religious tolerance like the one based on Pancasila's first principle. ${ }^{28}$ As mentioned earlier, measures in the time of the COVID-19 pandemic include several physical restrictions. These measures consider sociological factors of infected people and considering people who have been positively affected by the COVID-19.

This COVID-19 has detrimental effects on humans, suggesting that the government introduce physical distancing and large-scale social restriction. Then, these measures affect the slowdown of economic growth. ${ }^{29}$ What has been taken by the government places Indonesia as the first Asian country to issue Global Bonds since the advent of the COVID-19 pandemic. It is to maintain safe financing and increase foreign exchange reserves for Indonesian banks. ${ }^{30}$ Given the importance of the national economy, a significant warning is then hit by a lockdown. The prohibition of activities is also very influential on the economy. The impact experienced by the economic sector are: First, the number of workers who were later dismissed and exposed to layoffs due to the impact of COVID-19, which affected the company. ${ }^{31}$ Second, almost all of the prices that then existed in marketing rose, to the point that without exception gold and

25 Max Roser et al., Coronavirus Disease (COVID-19) - Statistics and Research - Our World in Data, (2020) Our World Data, at 1-42.

26 Umma Farida, Diskursus Sunnah Sebagai Sumber Hukum Islam: Perspektif Ushuliyyin dan Muhadditsin, (2015) 6:1 Jurnal Pemikiran Hukum dan Hukum Islam, at 237-255.

27 Ali Sodiqin, Positifikasi Hukum Islam di Indonesia: Prospek dan Problematikanya, (2012) 1:2 Supremasi Hukum, at 446-462.

28 Boniy Taufiqurrahman, Pancasila dan Keberhasilan Sikap Toleransi Beragama pada Pemuda Desa Pengaringan Kecamatan Pejagoan Kabupaten Kebumen, (2018) Researchgate.net, at 0-9.

29 Chairul Iksan Burhanuddin \& Muhammad Nur Abdi, Ancaman Ekonomi Krisis Global dari Dampak Penyebaran Virus Corona, (2020) 17:1 AkMen, at 90-98.

30 Silpa Hanoatubun, Dampak COVID-19 terhadap Perekonomian Indonesia, (2020) 2:1 EduPsyCouns Journal of Education Psychology and Counseling, at 146-153.

31 Ibid. 
some other foodstuffs, this created an economic problem for people who were below average. ${ }^{32}$ Third, material that has been imported will be reduced by seeing the number of workers who have been laid off and laid off. ${ }^{33}$ Fourth, flight activity was temporarily terminated. As a result, domestic revenues from flights have significantly dropped because the number of tourists ceased to arrive in Indonesia. ${ }^{34}$ Fifth, the government's income through taxes from companies and hotels has dramatically due to Covid-19 as a subsequent severe impact due to flight termination..$^{35}$

This outbreak depends upon fundamental issues on economic, social, and religious activities, both for citizens and religious communities. It also deals with the economic gap and disparity due to the financial challenges during the COVID-19 pandemic. However, businessmen's losses can survive themselves as their other existing investments back them up. Suppose all individuals, business entities, non-business organizations, and all parts of a country can get through a crisis, survive, and return to production. In that case, national losses will eventually be covered. ${ }^{36}$ As for economic factors declining due to limited social activities, this makes the production system. Islamic da'wah may contribute to this recovery by considering it from the human aspect, which then impacts the poor to do mu'amalah because of the social restrictions. It refers to Surah an-Nisa: 29, which states, "O you who believe, do not eat your neighbor's property by way of naked, except by way of trade that applies with equal liking among you." The economy is a matter for citizens and communities. However, the imposition of social restrictions encourages restriction and close the trading business to prevent COVID-19. On the other hand, the community has much distress. As a result, Islamic da'wah reminds humans always to be grateful for Allah's fixed funds endeavors. Muslims will feel sufficient. It is because utilizing the existing resources means a sign of gratitude to God. It may be relevant to human rights obligation belongs to the government. According to Monzer Kafh, the government remains responsible for humans at the time of the COVID-19 pandemic. ${ }^{37}$

In anthropological terms, the COVID-19 pandemic has become an obstacle to perform religious worship. ${ }^{38}$ One of which is for Muslims to carrying out prayer's obligation in the congregation hindered by this pandemic, as the government encourages to perform it temporarily at home. It may contradict Islamic teaching, for which Islamic prayer in a congregation is categorized as people who believe in Allah. It refers to Surah At-Taubah: 18 states that only those who prosper the mosques of Allah are those who believe in Allah and the next day and continue to establish prayers.

32 Ibid.

33 Ibid.

34 Ibid.

35 Ibid.

36 Wibowo Hadiwardoyo, Kerugian Ekonomi Nasional Akibat Pandemi COVID-19, (2020) 2:2 BASKARA Journal of Business and Entrepreneurship, at 83-92.

37 Yenti Sumarni, Manajemen Ekonomi Islam dalam Menangani Pandemi Coronavirus Disease (COVID-19) di Indonesia, (2020) 5:1 Jurnal Baabu Al-Ilmi, at 122.

38 Abdul Mu'ti, Religious Communities Join Fight Against COVID-19, (2020), online: 〈https:/www. thejakartapost.com/academia/2020/06/12/religious-communities-join-fight-against-covid-19.html>. 
While the government takes measures related to COVID-19, the Indonesian Ulema Council or Majelis Ulama Indonesia (MUI), Indonesia's Muslim institution, issues the same to the propositions that already exist in Al-Qur'an through its fatwa or declaration Number 14 of 2020 on Organizing Worship in the Situation of COVID-19. This fatwa negates Friday prayers and five-time congregational prayers in mosques, categorized as a dangerous area or red zone. This fatwa also forbids those infected with the plague from Friday prayers and congregational prayers at the mosque. This MUI fatwa got support from religious organizations, such as NU and Muhammadiyah. ${ }^{39}$

That fatwa then becomes an obstacle for Islamic religious communities is the limitation of praying in congregation in the mosque. As a result, Muslim communities should perform prayers at home. In this case, the Islamic religious community can only endeavor and always pray to avoid COVID-19. All these obstacles then stem from an outbreak that has caused the government to issue a measure. It asserts that the government does not divide between the state and religion. The limitation of religious activities in public infrastructure is not a kind of a religious restriction. However, it is the way the government ensures public health from the COVID-19 transmission. This will become a significant obstacle because every religion has its day of existence. That measure is certainly not easy to be implemented in Indonesia. This is because the Indonesian Muslims are used to praying in public infrastructure (mosque) in largescale participants. It embeds Indonesian citizens with cooperation. The tradition of joy gather, which becomes among the main challenges to implementing physical distancing or worship restrictions.

Indonesia is a multi-religion country. Each adherent of certain religion performs worship in different ways. Activities of religious communities can help in appealing by giving an understanding of those religious communities. This is based on the existence of religious leaders who are then trusted to give advice. ${ }^{40}$ The power of religious community cohesiveness can be fundamental in breaking the spread chain by reminding each other. This can then make the government focus on finding drugs or solutions so that the virus-19 can be resolved or eliminated. ${ }^{41}$ Indonesia's legal system provides an understanding that the rule of law refers to norms, including religious norms. Thus, the government must consider the field's deeds to avoid the possible dispute between state and society. The Indonesian Institute of Science or Lembaga Ilmu Pengetahuan Indonesia (LIPI) identifies three aspects of why COVID-19 in Indonesia remains challenging. One of them is due to the disobedience of society that remains organizing mass worship. ${ }^{42}$ As a result, it is a test for religious communities in Indonesia to adapt to the new way of worship in the COVID-19 pandemic. They thrive on believing, praying, and be sincere in responding to the pandemic. Another challenge

39 Dedi Supriyadi Ayi Yunus Rusyana, Fatwa Penyelenggaran Ibadah di Saat Pandemi COVID-19 di Indonesia dan Mesir, (2020) 20:1 Asy-Syariah, at 1-14.

40 Abdul Mu'ti, supra note 39.

41 Ibid.

42 Andri Saubani, “Tiga Penyebab Indonesia Sulit Atasi Pandemi Covid-19”, (2020), online: Republika 〈https://republika.co.id/berita/qadh90409/tiga-penyebab-indonesia-sulit-atasi-pandemi-covidl9». 
that remains is the habit of mass prayer every night preceded Friday. ${ }^{43}$ Many Indonesian Muslims believe that this time is the night of glory or a holy day. Because of the COVID-19, it may change Muslims' habits. However, it needs to be eliminated first and still carry out individually for the sake of health and mutual benefit.

The impact of the COVID-19 is most striking in the life of human diversity, more specifically, Muslims. ${ }^{44}$ It can be seen at the time of Ramadan. For example, Muslims continue to carry out the advice to carry out tarawih prayers and Eid Fitri in the congregation at home. In this month of Ramadan, there is only once a year. Not necessarily the Muslim community can meet the next Ramadan. Citizens confirmed to be the COVID-19 carriers are classified as sick. Thus, they are waived not to fasting because it is feared that it will impact their worsen health. ${ }^{45}$ However, in Islam, there is a human aspect provided based on the command of Prophet Muhammad to remain in the house. It is reported in the Hadith by Bukhari and Muslim from Usman bin Zaid. It outlines that if someone hears about infections in a country, the prohibition can apply to enter. If someone is infected, it is to be forbidden to leaving it. Several conditions ('udzur syar'i) cause these obligations to fall, including heavy rain, illness, and strong winds. ${ }^{46}$

COVID-19 does not only harm religious communities but also global citizens. The COVID-19 pandemic may be adzab for the infidels and a test for Muslims through the Islamic lens. It is raised by the argument that nothing happens in this world but under permission from Allah. ${ }^{47}$ Therefore, some Muslims suggest drawing closer to God to ask forgiveness and pray for all humans to avoid this dangerous pandemic. Spirituality may be a good sedative in societies facing the outbreak. ${ }^{48}$ Both spirituality and religion can help humans in bereavement and time of crisis, ${ }^{49}$ including in the time of the current COVID-19 pandemic. Although Muslims must pray at home, spirituality can help people to be closer to God. Muslims have done valuable protective activities to combat the spread of this COVID-19 pandemic, such as canceling the Friday prayer and

43 Sumarni, Persepsi masyarakat islam terhadap tradisi yasinan pada malam jumat (studi kasus pondok pesantren annahdlah) Universitas Hasanuddin, 2018).

44 Abdul Syatar, Muhammad Majdy Amiruddin \& Arif Rahman, "Darurat Moderasi Beragama di Tengah Pandemi Coronavirus Desease 2019 (Covid-19)” (2020) Vol. 13: No.l J Media Komun Sos dan Keagamaan 1-13.

45 Gampang Dadiyono \& \&arzuki Umar, "Hukum Berpuasa Dalam Kondisi Pandemi COVID-19” (2020) Vol. l:No. 2 J Bid Huk Islam Hal. 197-208.

46 Alif Jumai Rajab, Muhamad Saddam Nurdin \& Hayatullah Mubarak, "Tinjauan Hukum Islam Pada Edaran Pemerintah dan MUI Dalam Menyikapi Wabah COVID-19” (2020) Vol. 1:No. 2 J Bid Huk Islam Hal. 156-173.

47 Syandri Ronny Mahmuddin, "Qadariyah, Jabariyah dan Ahlussunnah (Studi Komparatif Merespon Kebijakan Pemerintah dan Fatwa MUI Dalam Mencegah Penularan COVID-19)” (2020) Vol. 1:No. 2 J Bid Huk Islam Hal. 209-222.

48 Valliant GE, "Psychiatry, Religion, Positive Emotions and Spirituality" (2013) 6:6 Asian J Psychiatry 590.

49 Karolina Krysinska, Karl Andrlessen \& Jozef Corveleyn, "Religion and Spirituality in Online Suicide Bereavement: An Analysis of Online Memorials" (2014) Crisis 349-356. 
congregational prayer. ${ }^{50}$ This case usually happens in some countries, like Ebola in Nigeria. The Federal Government of Nigeria advised taking Prophet Muhammad's counsel, who frequently urged Muslims to cleanliness and wash their hands. ${ }^{51}$ The restriction of worship during the COVID-19 pandemic should not be interpreted as an obstacle to worship. However, it should be believed as a way to get more closer to God.

\section{CONCLUSION}

The COVID-19 pandemic has become a worldwide alarm regarding human's causeddamage. The historical aspect indicated that the advent of COVID-19 becomes a challenge for humans in performing worship. It is allowed for Muslims to perform worship at home to avoid the possible larger carriers to COVID-19. It was experienced by Muslims in Muhammad Prophet and some other subsequent periods that endanger not only Muslims but all citizens. Nevertheless, the difficult situation due to the absence of a vaccine and effective treatment to overcome urges all the relevant elements remaining to practice the health protocols. However, it also indicates to offer an approach for religious adherents, especially Muslims, to remember God. It is because the COVID-19 pandemic may be adzab for the infidels and a test for Muslims, as nothing happens in this world but permission from Allah.

\section{ACKNOWLEDGMENTS}

None.

\section{COMPETING INTERESTS}

The authors declare that they have no competing interests.

\section{REFERENCES}

Alchon, Suzanne Austin, A Pest in the Land: New World Epidemics in a Global Perspective (Mexico City: University of New Mexico, 2003).

Azizah, Bintu Syaifa Al, Al-Wabâ wa al-Hijr as-Shihhi fî Dhơi al-Sunnah al-Nabawiyyah alSyarîfah UIN Syarif Hidayatullah Jakarta, 2020).

Bukhari, Muhammad ibn Ismail, Sahih al-Bukhari (Beirut: Dar Ibn i Katsir, 202AD).

Sumarni, Persepsi masyarakat islam terhadap tradisi yasinan pada malam jumat (studi kasus pondok pesantren an-nahdlah) Universitas Hasanuddin, 2018).

Ahmad, Zohaib \& Arzoo Ahad, "COVID-19: A Study of Islamic and Scientific Perspectives" (2020) 0:0 Theol Sci 1-10.

50 J Fischer et al, "Influence of culture and religion on the therapy of cancer patients" (2019) 58:10 The Urologist 1178-1184.

51 Maigari YT, "The relevance of the Islamic principles on cleanliness to contemporary times: Focus on hand washing" (2016) 6:2 Ilorin J Relig Stud 9l-104. 
Ali Sodiqin, "Positifikasi Hukum Islam di Indonesia: Prospek dan Problematikanya" (2012) vol 1:2 Supremasi Huk 446-462.

Alif Jumai Rajab, Muhamad Saddam Nurdin \& Hayatullah Mubarak, "Tinjauan Hukum Islam Pada Edaran Pemerintah dan MUI Dalam Menyikapi Wabah COVID-19" (2020) Vol. 1:No. 2 J Bid Huk Islam Hal. 156-173.

Ayi Yunus Rusyana, Dedi Supriyadi, "Fatwa Penyelenggaran Ibadah di Saat Pandemi COVID-19 di Indonesia dan Mesir" (2020) vol 20:1 Asy-Syariah 1-14.

Dadang Darmawan, Deni Miharja, Roro Sri Rejeki Waluyojati \& Erni Isnaeniah, "Sikap Keberagamaan Masyarakat Muslim Menghadapi Covid-19” (2020) 4:No. 2 J Studi Agama-Agama Dan Lintas Budaya 1-10.

Dadiyono, Gampang \& Marzuki Umar, "Hukum Berpuasa Dalam Kondisi Pandemi COVID-19" (2020) Vol. 1:No. 2 J Bid Huk Islam Hal. 197-208.

Eko Misbahuddin HasibuanMuhammad Yusram, "Hukum Salat Berjemaah di Masjid dengan Saf Terpisah Karena Wabah COVID-19” (2020) l:No. 2 J Bid Huk Islam Hal. 106-124.

Eman Supriatna, "Wabah Coronavirus Disease COVID-19 Dalam Pandangan Islam" (2020) Vol. 07:No. 6 J Sos Budaya Syar- FSH UIN Syarif Hidayatullah Jkt 555564.

Farida, Umma, "Diskursus Sunnah Sebagai Sumber Hukum Islam: Perspektif Ushuliyyin dan Muhadditsin" (2015) 6:1 J Pemikir Huk Dan Huk Islam 237-255.

Fischer, J et al, "Influence of culture and religion on the therapy of cancer patients" (2019) 58:10 The Urologist 1178-1184.

GE, Valliant, "Psychiatry, Religion, Positive Emotions and Spirituality" (2013) 6:6 Asian J Psychiatry 590.

Hadiwardoyo, Wibowo, "Kerugian Ekonomi Nasional Akibat Pandemi Covid-19" (2020) 2:2 BASKARA J Bus Entrep 83-92.

Hasbiyallah et al, "Fikih Corona (Studi Pandangan Ulama Indonesia terhadap Ibadah dalam Kondisi Dharurat Covid-19)" (2020) vol.1:No.2 J Fikih Islam 1-8.

Iksan Burhanuddin, Chairul \& Muhammad Nur Abdi, "Ancaman Ekonomi Krisis Global Dari Dampak Penyebaran Virus Corona” (2020) 17:1 AkMen J Ilm 90-98.

Krysinska, Karolina, Karl Andrlessen \& Jozef Corveleyn, "Religion and Spirituality in Online Suicide Bereavement: An Analysis of Online Memorials" (2014) Crisis 349-356.

Kustana et al, "Analisis Kritis Pola Keberagamaan Dalam Perubahan Sosial di Tengah Wabah COVID-19" (2020) l:No. 2 J Anal hal 1-7.

Lai, Chih Cheng et al, "Severe acute respiratory syndrome coronavirus 2 (SARS-CoV-2) and coronavirus disease-2019 (COVID-19): The epidemic and the challenges" (2020) 55:3 Int J Antimicrob Agents 105924.

Masson, Adèle de et al., "Chilblains is a common cutaneous finding during the COVID19 pandemic: A retrospective nationwide study from France" (2020) 83:2 J Am Acad Dermatol 667-670.

Max Roser et al., "Coronavirus Disease (COVID-19) - Statistics and Research - Our World in Data" (2020) Our World Data 1-42.

Mukran H Usman, "COVID-19 Dalam Perjalanan Akhir Zaman: Sebab, Dampak dan Anjuran Syariat Dalam Menghadapinya” (2020) vol 01:2 J Bid Huk Islam 137155.

Riksa Buana, Dana, “Analisis Perilaku Masyarakat Indonesia dalam Menghadapi Pandemi Virus Corona (Covid-19) dan Kiat Menjaga Kesejahteraan Jiwa" (2020) 7:3 J Sos Dan Budaya Syar-I 221. 
Ronny Mahmuddin, Syandri, "Qadariyah, Jabariyah dan Ahlussunnah (Studi Komparatif Merespon Kebijakan Pemerintah dan Fatwa MUI Dalam Mencegah Penularan COVID-19)" (2020) Vol. 1:No. 2 J Bid Huk Islam Hal. 209-222.

Silpa Hanoatubun, "Dampak Covid - 19 terhadap perekonomian Indonesia" (2020) 2:1 EduPsyCouns J Educ Psychol Couns 146-153.

Sumarni, Yenti, "Manajemen Ekonomi Islam dalam Menangani Pandemi Coronavirus Disease (COVID-19) di Indonesia" (2020) 5:1 J Baabu Al-Ilmi 122.

Susilo, "Coronavirus Disease 2019: Tinjauan Literatur Terkini" (2020) 7:No. 1 J Penyakit Dalam Indones 1-67.

Suyadi, Zalik Nuryana \& Niki Alma Febriana Fauzi, "The fiqh of disaster: The mitigation of Covid-19 in the perspective of Islamic education-neuroscience" (2020) 51 Int J Disaster Risk Reduct 101848.

Syatar, Abdul, Muhammad Majdy Amiruddin \& Arif Rahman, "Darurat Moderasi Beragama di Tengah Pandemi Corona Virus Desease 2019 (Covid-19)" (2020) vol 13:No.1 J Media Komun Sos Dan Keagamaan 1-13.

Taufiqurrahman, Boniy, "Pancasila dan Keberhasilan Sikap Toleransi Beragama pada Pemuda Desa Pengaringan Kecamatan Pejagoan Kabupaten Kebumen" (2018) November Researchgate.net 0-9.

YT, Maigari, "The relevance of the Islamic principles on cleanliness to contemporary times: Focus on handwashing" (2016) 6:2 Ilorin J Relig Stud 91-104.

Abdul Mu'ti, "Religious communities join fight against COVID-19", (12 June 2020), online: Opinion - Jkt Post 〈https://www.thejakartapost.com/academia/2020/06/12/ religious-communities-join-fight-against-covid-19.htmls.

Afifah, Nur, Islam dan COVID-19, by Nur Afifah (Ponorogo, 2020).

ECFR, "The European Council for Fatwa and Research: Renewed leadership, renewed hopes" (2018).

Saubani, Andri, "Tiga Penyebab Indonesia Sulit Atasi Pandemi Covid-19", (2020), online: Republika 〈https://republika.co.id/berita/qadh90409/tiga-penyebabindonesia-sulit-atasi-pandemi-covid19>. 